\title{
DIE KERK VAN CHRISTUS IN AFRIKA
}

\section{(KERKLIKE EENHEID)}

\section{Kerklike agtergrond}

1. Met die eerste uitbreiding van die Christendom na Afrika in die begin van onse jaartelling, was die kerk nog ' $n$ eenheid. Oorblyfsels van die Apostoliese Kerk na die teëslag van die Mohammedanisme vind ons slegs nog in die Koptiese Ortodokse Kerk en die Armenies Evangeliese Kerk in Egipte en in die Etiopiese Kerk in Etiopië en Eritrea, in soverre dit nog daarin herkenbaar is. Met sy tweede aanslag op Afrika sinds die 17e eeu was die Christelike kerk 'n verdeelde kerk. Afrika laat die Christelike kerk homself soos in 'n spieël sien in sy opgebrokenheid.

2. Die beeld van die kerk in Afrika is ongeveer soos volg: Van die $220,000,000$ inwoners word ongeveer $50,000,000$ getel as Christelik (25\%) teenoor $60,000,000$ Mohammedane $(30 \%)$ en $120,000,000$ Heidene (45\%). Teenoor hierdie oorwig staan die Christendom verdeeld tussen die Rooms-Katolieke Kerk $(30,000,000)$ en die Protestantse kerke $(20,000,000)$ met ongeveer 5 miljoen Ortodokse.

3. Teenoor die Rooms-Katolieke Kerk staan die Protestantse kerke verdeeld met al sy gevestigde kerke, ook weer in húlle onderverdelinge, verteenwoordig in Afrika: Anglikaanse Kerk(e), Presbiteriaanse Kerk(e), Metodistiese Kerk(e), Kongregasionalistiese Kerk(e), Baptiste Kerk(e), Lutherse Kerk (e), Gereformeerde Kerk(e), altesaam ongeveer 30 verskillende kerkgemeenskappe. Hierby is sektes, w.o. Onafhanklike (Afrika-) kerke en Separatistiese kerkgroepe wat by duisende tel, in Suid-Afrika alleen meer as 2,000, nie bygereken nie. Wat die Afrikalande betref is 30 uit die 44 Rooms. Oorwegend Protestants is: Suid-Afrika, Suidwes-Afrika, Betsjoeanaland, Rhodesië, Zambië, Njassaland, Ghana, Liberië, Sierra Leone en Madagaskar.

4. Teenoor die magte van Heidendom en Mohammedanisme en die eenheid van die Rooms-Katolieke Kerk het juis in Afrika die vraagstuk van die eenheid van die kerk na vore getree in sy skerpte en aktualiteit. Dit kry nog verdere aksent deur die ontstaan van die onafhanklike state in Afrika, waardeur veral die Protestantse kerke getref word met 'n nuwe 
verdelingslyn, naamlik 'n nasionale by die konfessionele. W. Bühlmann kan verklaar: „Die Katholische Kirche stellt in Afrika eine Macht ersten Ranges dar... Es gibt in Afrika schlechthin keines andere Organisation, die über solche Mittel verfügt und sich über die ganzen Kontinent erstreckt" (Afrika, Die Kirche unter den Völker, p. 67).

Die hele Afrika word gesien as territoriaal, met sy kerke en sendinggebiede, behorend tot die Rooms-Katolieke Kerk. Dit is as geheel verdeel in bisdomme of toekomstige bisdomme, selfs waar die Roomse sending pas begin met, of nog in die geheel nie. Terwyl Bühlmann 'n hele hoofstuk wy aan die nie-Christelike en anti-Christelike Afrika (Heidendom, Islam, Materialisme, Kommunisme) word die Protestantse kerk as „Getrennte Kirche" in 'n paragraaf afgehandel.

\section{Motiewe}

5. Die eenheid van die kerk word gegrond op Skrif en Belydenis. As die Skrif van die kerk spreek as die Liggaam van Christus (o.a. Ef. 1:23), moet dit as sodanig ook sigbaar tot openbaring kom. Die belydenis van die "heilige algemene, Christelike kerk" moet ook omgesit word in die daad. Daar word steeds herinner aan die bekende woorde van Christus in die hoëpriesterlike gebed: „dat hulle almal een moet wees, net soos Ons een is... dat die wêreld kan weet dat U My gestuur het" (Joh. $17: 22,23$ ).

6. By die prinsipiële kom ook praktiese oorwegings, veral tweërlei:

Eerstens dat die konfessionele verskille wat in die loop van die eeue ontstaan het, van buite af ingedra is in Afrika en dit vir die Christen van Afrika nie die betekenis het wat dit vir die kerke het, wat die draers van die verskillende tradisies is nie;

tweedens die noodsaaklikheid met die oog op eenheidsoptrede in die wêreld.

Op die laaste val alle nadruk, soos blyk uit die volgende sterk verklaring van die All African Conference of Churches: "The extent to which the division of the Church, transplanted from the West to Africa, are detrimental to its mission has been repeatedly pointed out... This problem can no longer be regarded as only a "domestic" affair or an internal problem of the churches and missions. From the standpoint of both 
service and witness, the divided church is a scandal which cannot be tolerated any longer. The issue must not be dismissed simply by saying that denominational/confessional differences mean nothing to the African, either before or after he has become a Christian, and that therefore the problem lies with the parent-bodies in the West. The issue of church unity can be approached most properly in terms of the Church's confrontation with the world. In Africa as in Asia this confrontation can be seen in a much more radical fashion than in the "Christian" society of the West" (Africa in Transition, p. 88).

\section{Vorme}

7. Die beeld van Afrika met sy veelheid van kerke word nog ingewikkelder deur die veelheid van eenheidsbewegings. Daar is dié waarby dit gaan om verwante kerkgroepe, in dieselfde land (nasionaal) soos die Evangeliese Alliansie in Angola, die Evangeliese Federasie van Kameroen en Sentraal Afrika-Republiek, die Protestantse Konsilie van die Kongo, die Christelike Instituut van die Kongo. Die Christian Council of Churches is inklusief, of bedoel om dit te wees. Hoewel selfstandig in elke land, staan dit in nou verband met die Wêreld raad van Kerke. In Afrika bestaan dit in 11 lande.

8. Verder is daar internasionale eenheidsbewegings tussen (minder of meer) verwante groepe wat beslag gekry het o.a. in die Lutherse Wêreldfederasie, die Wêreld Presbiteriaanse Alliansie, die Baptiste Wêreldalliansie, die Metodistiese Wêreldraad, die Internasionale Raad van Christelike Kerke, die Geref. Ekumeniese Sinode (uit Afrika gebore). Die inklusiewe beweging is hier die Wêreldraad van Kerke. So ook die All African Conference of Churches (A.A.C.C.), wat omvattend is, of wil wees t.o.v. die kerke, maar beperk wil wees tot Afrika. Om hierdie groepering volgens omvang volledig te maak moet naas hierdie nasionaal-interkerklike en die internasionaal-interkerklike die internasionaal-kerklike (konfessionele) genoem word. Die enigste wat hieronder val is, behalwe die RoomsKatolieke Kerk, die Lambeth Conference.

9. Die bontheid van hierdie kerklike eenhede en eenheidsbewegings blyk verder uit die name waarmee dit aangedui word soos alliansie, raad (konsilie), konferensie, federasie. Wat Afrika in besonder betref, bv. The American Wes- 
leyan Church of Sierra Lcone, The Methodist Church in U.S.A. in S.A., New Jerusalem in the U.S.A. in S.A. In hierdie verband blyk ook die vreemdheid van name soos: The Church of England in South Africa ens., en van 'n Church of Scotland en 'n United free Church of Scotland in S.A.

10. Wat die vorm van die eenheidsbewegings betref moet ook onclerskei word tussen die wat 'n korporatiewe en die wat 'n koöperatiewe eenheid beoog. Voorbeelde van die eerste in Afrika is die eenheidsbewegings wat vorm aangeneem het, of besig is om vorm aan te neem, in Sentraal-Afrika (United Church of Central Africa in Rhodesia), in Nigerië, Ghana, OosAfrika, e.a. Voorbeeld van die tweede is die A.A.C.C. Die eerste sluit aan by die beweging Faith and Order, wat stam uit die 19e eeu (Oxfordbeweging) en beslag gekry het in die Commission and Department on Faith and Order van die W.R.K. Die tweede sluit aan by die beweging Life and Work, ontstaan na die Eerste Wêreldoorlog en waaraan die naam van biskop Söderblom van Swede (Stockholm) verbind is. Hierdie tweede beweging, in besonder, het beslag gekry in die W.R.K.

11. In Ghana en in Oostelike Afrika is die bemoeiinge om een nasionale kerk (vgl. 10) die verste gevorder (behalwe in Nigerië en Sentraal-Afrika, waar dit reeds vaste vorm aangeneem het - die basisse was egter nie beskikbaar nie) met hulle basisse van eenheid reeds vasgelê met die oog op finale goedkeuring. Hier word ten nouste aangesluit by die van Nigerië en by dergelike basisse in Indië (Suid- en Noord-), Pakistan en Australië. In Ghana gaan dit om die vereniging van die Anglikaanse Kerk, die Evangelies-Presbiteriaanse Kerk, die Presbiteriaanse Kerk van Ghana en in Oostelike Afrika om die Anglikaanse, Lutherse, Moraviese en Presbiteriaanse Kerke van Tanzanië en Kenya. Op die jongste konferensie in Dodoma, begin 1965, waar besluit is tot ' $n$,,interim basis of union" het die Lutherse en Moraviese Kerke voorlopig teruggestaan op grond van die aanvaarde suksessie-gedagte in die kerk.

12. Enkele aanhalings uit die basisse, wat vir hulself spreek: „Though we were established as separate Churches in Ghana through the missionary zeal of Christians in other lands, we desire to heal these historic separations, without the surrender of any principle of Faith and Order, which through mutual prayer and deliberation, we believe to be within the will of God for the One Holy Catholic and Apostolic 
Church of which our Lord Jesus Christ is the Founder and Head" (Basis of Union, Ghana, p. 9). Ongeveer dieselfde gcdagtegang word gevind in die Interim Basis (o.a. p. 11), waar een en ander sterker gestel word, o.a. „Historically, we are heirs of their separateness" en ook verder uitgebrei word: „We are agreed in seeking a united Church which, as a manifestation of the One Church of Jesus Christ throughout the world, will also develop in the expression of its worship, its faith and its common life, the distinctive gifts which God has given to His people of East Africa”; i.p.v. „,which, as a manifestation..." het Ghana: ,... an integral part of the Universal Church".

13. Wat die konfessie betref word van die onderhandelende kerke gesê: "They accept the Holy Scriptures of the Old and New Testaments recording Gods redemptive acts as The Word of God, in which are found all things necessary for salvation, and which is the supreme and decisive standard of faith" (E.A., p. 14, Ghana id. p. 11). Verder word die Apostoliese Geloofsbelydenis en die van Nicea aanvaar.

O.A. voeg by: „In this process (of growing together into one life and of advance towards full spiritual unity), we do not desire that one Church shall absorb other Churches, nor that one tradition shall be imposed upon all; but rather that each Church shall bring the true riches of its inheritance into the united Church to which we look forward" (p. 13).

Ghana het dieselfde en laat volg: „While the negotiating Churches have taken traditional statement of faith (The Apostles and Nicene Creeds) as sufficient to serve as 'n basis of union, they are agreed that the Church has a continuing responsibility to make its faith clear both to itself and to those outside, restating that faith in relation to the contemporary situation in which the church stands and in relation to the beliefs, hopes and fears of the world around it. They believe that it should be an early task of the united Church to take up this responsibility" (p. 12).

14. By die kerkregering word elemente opgeneem van al die konstituerende kerke. Daar sal wees 'n General assembly, 'n Diocesan Synod, 'n District Session (Ring of Klassis) 'n 'n Diocesan Synod, 'n District Session (Ring of Klassis), 'n word verbind met die biskoplike stelsel, met die leer van die biskoplike suksessie. Die implikasie is dat die kerk of 'n afgeslote nasionale eenheid vorm ò as nasionale kerk afhank- 
lik word van die aartsbiskop van Canterbury. Die besluit is: „The united Church shall be an autonomous Church and free from any control, legal or otherwise, of any Church or Society external to itself". Die Verenigde Kerk wil egter gemeenskap onderhou met ander binnelandse kerke en oor die wêreld in gehoorsaamheid aan Christus die hoof van die hele kerk (E.A., p. 28, Ghana, p. 27). Ondanks die laaste is konfessionele verdeling deur 'n nasionale vervang.

15. ' $n$ Kort historiese oorsig in die inleiding op die interimbasis van O.A. bevat die mededeling dat in dit wat in Dodoma, 1965, tot stand gekom het die bekroning gesien moet word van bemoeiinge wat in 1913 begin is in Kikuju, naby Nairobi. Daar het op die datum sendelinge uit Kenya en Uganda van die Anglikaanse, Metodistiese en Presbiteriaanse kerke byeen gekom met die oog op die vorming van 'n federasie van Sendinggenootskappe.

\section{Die boom en sy vrugte}

16. Die A.A.C.C. (vgl. par. 8 en 10) wil wees ,a fellowship of consultation and co-operation". Dil grond hom, as staande konferensie van kerke en Christenrade van Kerke (Christian Councils) in Afrika op die belydenis dat die Here Jesus Christus God en enigste saligmaker is in ooreenstemming met die Skrifte, en wil sy taak gemeenskaplik volbring tot eer van die enige God, Vader, Seun en Heilige Gees. (Art. 1).* Die (vaste) Algemene Komitee is gevestig op Kitwe. Die voorsitter en algemene sekretaris is resp. dr. D. G. S. M'Timkulu, oorspronklik uit S.A., en mnr. S. E. Amissah van Nigerië. Die eerste vergadering is gehou in Ibidan, Nigerië in 1958, en die stigtingsvergadering in Kampala, Uganda, in 1963. Intussen vergader verskillende komitees gereeld om opdragte uit te voer en voorbereidsels te mak vir die volgende Algemene Vergadering, D.V. in 1967. Van tyd tot tyd word konsultasies gehou. Die jongste het plaasgevind in Enugu, Nigerië, en het bestaan uit slegs nie-blanke kerkleiers.

17. Om 'n blik te gee in die aktiwiteite van die A.A.C.C. word aangesluit by die onlangse Konsultasie van Enugu, wat byeengeroep is deur die A.A.C.C. in samewerking met die

*) L.W.: By hierdie basis gaan dit om saamwerkende kerke en nie om 'n korporatiewe eenheid nie, vgl. par. 13, en om alle kerke in Afrika. 
Dept. Interchurch Aid, Refugee and World Service van die W.R.K. Die volgende sake was ter tafel:

1. Onderlinge kerklike hulp, ook internasionaal, vir kerkbou (veral geestelik verstaan) aan die jong selfstandiggeworde kerke in Afrika.

2. Nasiebou (betrokkenheid van die kerk hierin) op ekonomies-sosiale gebied (o.a. die belangrike plek van landbou in die sosio-ekonomiese ontwikkeling) en op politieke gebied.

3. O.a. die volgende: Die vlugteling-probleem; die plek van Afrika in internasionale sake; die verhouding van die A.A.C.C. tot die O.A.U. (Organisasie vir Afrika-eenheid) en die verhouding van eie nasieskap tot Afrika-eenheid; gebruik van kernwapens in die algemeen en in besonder die denuklearisering van Afrika; kolonialisme; probleme van kerk en sending in Angola; rasseprobleem in Rhodesië en "Apartheid" in S.A.

18. By die onderlinge kerklike hulp (Interkerklike Sustentasie) gaan dit in besonder om ondersteuning van Jeugsentra en Vroue-opleidingsentra, met die oog op opbouing van die jong kerke in die verskillende lande, wat nie in staat is om met eie middele te voorsien nie en hulp nodig het van alle kerke.

19. I.v.m. die sosio-ekonomiese ontwikkeling en die betrokkenheid (involvement) van die kerk daarby word daarop gewys dat dit gaan om ,,ideological issues” en verklaar: „Whatever system is adopted in the pursuit of rapid social and economic development, the Church should constantly keep before the planners the need for ensuring a wise and efficient use of capital and equitable distribution of the fruits of development" (Enugu, p. 94). Openlike en skerp kritiek het in hierdie verband uitgegaan van dr. S. A. Aluko van die Universiteit van Nigerië teen die onoordeelkundigheid en sug na weelde by die Afrika leiers (Enugu, p. 97) en verder „We would urge our nations to mobilize more than ever before the resources of our people, so that the contribution from foreign sources is merely to... complement what we are doing" (p. 107).

20. Nasiebou was die sentrale tema en die vraag van die betrokkenheid van die kerk daarby. Moet die kerk hierin afuysend, of, minstens afsydig staan soos geleer is van die 
kant van die Sendende Kerke? Of is die kerk ten diepste daarby betrokke ook wat die politieke aspek betref? Die antwoord is soos volg: ,it is impossible to isolate politics from the total life of society and of man, or not to support those Christians who for human and social reasons have entered into political action" (p. 95). Die kerk moet homself rekenskap gee en aan die wat daarby betrokke is voorligting gee van wat die Skrif leer m.b.t. die politieke orde.

21. Die vlugtelingprobleem: 500,000 Afrikane is voort vlugtig: 25,000 uit Angola na die Kongo (Leopoldville), uit Ruanda 40,000 na Uganda, 30,000 na Burundi, 12,000 na Tanzanië; 50,000 uit Soedan na Uganda, C.A. Republiek en Etiopië; vlugtelinge uit S.A., S.W.A. en Rhodesië na die Protektorate, Tanzanië en Nigerië, en uit Mosambiek na Nigerië.

Die oorsake is van politieke, ekonomiese en godsdienstige aard. Dit is ook as gevolg van stamonluste. In Angola word die Protestantse, in die Kongo die Roomse Kerk getref. In hierdie verband word 'n Afrika-wye roeping vir die kerk gesien. Dit bestaan o.a. in 'n behoorlike opname, in ondersteuning, in pastorale sorg, en ook in vertoë by die betrokke owerhede en die V.V.O.

22. "Apartheid" in S.A. en die rasseverhoudinge in Rhodesië word sterk veroordeel.

\section{Teologiese fundering}

23. Slegs enkele grepe word in hierdie verband gedoen: ".... the Tanganyika study has given specific attention to the question arising out of the background of pietistic theology which cast doubt on the justification of the involment of the Christian community in the sociological changes of a country" (p. 18).

24. „God is the God of history... In spite of what we may think about ourselves as 'masters of history', or such other selfcongratulating phrases... the Christian has to keep constantly in mind, that it is God Himself who is the architect and controller of history. The Christian has always to proclaim the sovereignty of Christ over te affairs of men and even over the whole of creation. It is God who brings changes about, we are His instruments; it is God who rules, we are His agents" (p. 21).

25. "Our African heritage has taught us that life cannot 
be divided into compartments but must be viewed as a totality. We are not interested in dividing life between the spiritual on the one hand and the material on the other. Christianity with its doctrine of the sovereignty of God reinforces this belief. "The earth is the Lord's and the fullness thereof, the earth and they that dwell therein' (Ps. $24: 1$ ). He is the Lord not only of our personal, family and church life, but also of our economic, political and international life... The Gospels also relate Christ to the whole creation, not a segment of it... Christ is the Word through whom the whole creation came into being and is the Redeemer of the whole creation. He is the King of all nations" met verwysing na Ef. en Kol. (Africa in Transition, p. 80 e.v.).

26. ,As Christ took the form of a servant and gave himself for redemption and reconciliation of the whole man and the whole world, Christians are called to take their part in his suffering and victorious ministry as servants of the Servant-Lord. The power for service is given by the Holy Spirit who uses the Church as instrument in manifesting the Kingdom of God and Lordship of Jesus Christ in all human relations and all social structures (p. 33)... The individual Christian and the Church have to stand within the process and exercise the ministry of reconciliation... our ministry of reconcliation keeps us from being completely identified with any party and therefore leaves us seemingly ignored by all" (Enugu, p. 42).

27. In verband met die kerk en die ekonomiese lewe, die volgende: ,In the providence of God, the means of subduing the earth and having dominion over the things of the earth is now available through the handmaid of science and technology... The Consultation recalled the principle of Christian stewardship whereby Christians see all the resources, material and human, at the disposal of man as a gift from God to man who holds it in trust for Him. Equitable, judicious, frugal and unselfish use of these in fostering economic development is as much to the glory of God as to the welfare of man" (p. 93).

\section{Konsiderasies}

28. As dit vreemd aandoen dat sake soos bogenoemde op 'n kerklike vergadering behandel word, dan word ter oorweging gegee: 
„The Christian revelation emancipated men's minds from the fears about the world and the universe which were hemming them in... The principalities and powers in earthly and heavenly places were conquered, the world and the universe were seen as Gods handwork. Christians must be concerned for a changing society since those very changes are being wrought by the technological developments and the social changes which accompany them which a Christian culture has fostered" (p. 39), en in samehang hiermee: „Part of the tragedy of our day is that Christians have rejected the revolution they created and others have stepped in to claim it, who had no part in creating it and whose political philosophies and social and economic theories cannot bring it to its fulfillment" (p. 38).

29. ' $n$ Verdere oorweging is juis die afwesigheid van ' $n$ Christelike maatskappy (vgl. die vorige referaat, parr. 31 en 32). Het die kerk dan nie 'n verantwoordelikheid in die noodtoestand wat die gevolg is van die snelle verandering nie?

„In fact, the churches and missions were in many situations initiators, ... 'prime movers' of social change and therefore are under obligation to be concerned about its consequences in as much as there are numerous moral and spiritual implications there" (Africa in Transition, p. 82). Trouens, so het Afrika die Christelike kerk leer ken in sy sending. Op die sendingveld was dic eerste skole, is die eerste akkerbou en die eerste nywerhede geleer: ,... in this way (the missionaries) helped the economic development of the area. They indeed substantially contributed to the shaping of Ghana" (Africa in Transition, p. 82).

30. Dit kom ten slotte neer op die vraag of so geskei mag word, vgl. par. 25, waar die eenheid van die kerk as organisme en as instituut gehandhaaf word, soos die eenheid van die sigbare en onsigbare kerk in par. 4. Dit is ook van belang i.v.m. die eenheid van die kerk. Dat die kerk in Afrika hom bewus is ook van e.g. onderskeiding blyk uit die volgende: „When we speak of the Church's participation we have to think of the different modes of the Church's life, each with its own appropriate patterns of action. The Church as an institution, organised in synods and assemblies, the Church as a people forming part of a larger community, the Church as laymen dispersed in the different activities of nation building" (Enugu, p. 93). 


\section{Die probleem}

31. Parr. 16 tot 22 het ons ongetuyfeld voor die vraag gestel of daar in geheel sprake kan wees van kerklike eenheid op internasionale vlak, selfs in die verswakte vorm van samewerkende kerke (,consultation and co-operation", A.A.C.C. konstitusie), soos parr. 11 tot 14 ons gebring het voor die probleem van die kerkverband na buite by kerklike eenheid op nasionale vlak (vgl. die alternatief daar: afhanklikheid van 'n buitelandse kerk of outonome nasionale kerke, waarvan begryplikerwys die laaste gekies is), sodat die kerklike eenheidstrewe in Afrika blykbaar uitloop op die dilemma: 'n Veelheid van Nasionale kerke of 'n kerklike eenheid ten koste van nasionale verbondenheid, of, wat op min of meer dieselfde neerkom: 'n Nasionaal bepaalde Christendom of 'n universele, waarin nasies verdwyn. Waarskynlik het ons in S.A. ook in die greep van hierdie skynbaar onversoenlike teëstelling geraak.

\section{VIII. „Kerk" en „kerke”}

32. In die Nuwe Testament kom die meervoud "kerke" net voor in betekenis van plaaslike kerke, wat elkeen 'n outonome kerk is as plaaslike openbaring van die Een Kerk: die Liggaam van Christus.

33. Hoewel outonoom, is die kerke nie onafhanklik nie, maar verplig om met mekaar in verband te tree omdat hulle die openbaring van die Liggaam van Christus is en ómdat die kerk as Liggaam van Christus Een is en Algemeen, moet die kerkverband in beginsel oor die nasionale grense gaan, d.w.s. ekumenies wees.

34. Die beeld wat die kerke in kerkverband moet ver toon is die van 'n gedifferensieerde eenheid: 'n Gedifferensieerde eenheid in die sin van nasionaal verbonde kerke, waarin die teëstelling versag word tot verskeidenhede in die Liggaam van Christus. Die eenheid beteken spanning, en in die weerstaan van, en die triomf oor die spanninge in die krag van Christus, kom dit tot openbaring as 'n eenheid van die kerk van Christus, ,wat albei in een liggaam met God versoen het" (Ef. $2: 16$ ) en aan wie Hy ook die bediening van die versoening gegee het ( 2 Kor. $5: 18$ ).

\section{Slot}

35. Die vraag is: Hoe moet ons kerklik teenoor die kerke 
van Afrika staan? Daar is drie moontlikhede:

1. Afsydig;

2. naas die veelheid van eenheidsbewegings moet nog een kom - die suiwere, soos ons dit sien;

3. aanknoop by die bestaande eenheidsbeweging, om die lig wat ons het te bring, hetsy deur die kerk, hetsy deur die A.C.B. of deur albei.

36. Oorweginge vir die laaste standpunt is o.a.:

1. Afrika het nie hierdie lig gehad en verwerp nie;

2. aan aanknopingspunte ontbreek dit nie, soos o.a. blyk uit die vorige referaat, $23-27$ en die nadruk op die verbondenheid van kerk en volk;

3. dit is die Reformatoriese weg;

4. dit bring by 'n derde vorm van kerklike enheid; die eerste is die van gewone kerkverband, naamlik waar eenheid is van belydenis en kerkregering; die tweede, die van samewerking in soverre daar ooreenstemming is; die derde, die van samespreking waar verskil bestaan.

P.U. vir C.H.O.

W. J. Snyman.

22 September 1965. 